\title{
PENGARUH PENDAPATAN ASLI DAERAH (PAD), DANA ALOKASI UMUM (DAU), SERTA BELANJA MODAL TERHADAP TINGKAT KEMANDIRIAN KEUANGAN DAERAH KABUPATEN/KOTA PROVINSI JAWA BARAT
}

\begin{abstract}
This study aims to find out how Local Revenue, General Allocation Funds, Capital Expenditures and District / City Regional Financial Independence Levels of West Java Province in 2014-2017 and to determine the partial and simultaneous effects of these variables. The sample used in this study was 27 districts / cities in West Java Province by using saturated census sampling or sampling methods to obtain 108 samples. The results of this study show that local revenue, general allocation funds, and capital expenditure have a simultaneous effect on the level of regional financial independence. Partially, regional original income has a positive effect on the level of regional financial independence, general allocation funds have no effect on the level of regional financial independence, capital expenditure has a negative effect on the level of regional financial independence.
\end{abstract}

ABSTRAK: Penelitian ini bertujuan untuk mengetahui bagaimana Pendapatan Asli Daerah, Dana Alokasi Umum, Belanja Modal dan Tingkat Kemandirian Keuangan Daerah Kabupaten/Kota Provinsi Jawa Barat Tahun 2014-2017 serta untuk mengetahui pengaruh parsial dan simultan diantara variabel tersebut. Sampel yang digunakan penelitian ini adalah 27 kabupaten/kota di Provinsi Jawa Barat dengan menggunakan metode sensus sampling atau sampling jenuh sehingga memperoleh 108 sampel. Hasil penelitian ini menunjukan pendapatan asli daerah, dana alokasi umum, dan belanja modal berpengaruh secara simultan terhadap tingkat kemandirian keuangan daerah. Secara parsial, pendapatan asli daerah berpengaruh positif terhadap tingkat kemandirian keuangan daerah, dana alokasi umum tidak berpengaruh terhadap tingkat kemandirian keuangan daerah, belanja modal berpengaruh negatif terhadap tingkat kemandirian keuangan daerah.
Nareswari Listya Nindita ${ }^{1}$, Sri Rahayu ${ }^{2}$

${ }^{1,2}$ Fakultas Ekonomi \& Bisnis, Universitas Telkom Dayeuhkolot, Bandung,

Keywords: Capital

Expenditures, General Alocation Funds, Level of Regional Financial Independence, Regional Income.

Kata Kunci: Belanja Modal, Dana Alokasi Umum, Pendapatan Asli Daerah, Tingkat Kemandirian Keuangan Daerah. 


\section{Pendahuluan}

Dalam penyelenggaraan pemerintah daerah di Indonesia diselenggarakan berdasarkan asas otonomi daerah yang dimana merupakan hak, wewenang, dan kewajiban daerah otonom untuk mengatur dan mengurus sendiri urusan pemerintahan dan kepentingan masyarakat setempat daerah itu sendiri untuk mengatur jalannya pemerintahan daerahnya secara mandiri. Menurut UU No.23 Tahun 2014, kemandirian keuangan daerah merupakan daerah berarti pemerintah dapat melakukan pembiayaan dan pertanggungjawaban keuangan sendiri, melaksanakan sendiri dalam rangka asas desentralisasi. Kemandirian keuangan suatu daerah dapat dilihat dari besar atau kecilnya pendapatan asli daerah tersebut dibandingkan tingkat pendapatan daerah dari sumber lain seperti bantuan pemerintah pusat maupun dari pinjaman lainnya (Susanti et al, 2016).

Pada provinsi Jawa Barat, pada tahun 2014-2017 rata-rata Tingkat Kemandirian Keuangan Daerah (TKKD) mengalami peningkatan tetapi masih termasuk dalam kategori rendah atau dengan pola hubungan konsultatif. Walaupun rata-rata kemandirian keuangan daerah pada kabupaten/kota meningkat setiap tahunnya, tetapi masih sedikit kabupaten/kota di provinsi Jawa Barat yang sudah dinyatakan sebagai daerah yang memiliki tingkat kemandirian yang tinggi dibandingkan dengan daerah yang memiliki tingkat kemandirian yang rendah atau bahkan sangat rendah selama kurun waktu 2014-2017. Berikut adalah rata-rata Tingkat Kemandirian Keuangan Daerah seluruh kabupaten/kota provinsi Jawa Barat pada tahun 2014-2017:

\section{Tabel 1. Rata-Rata Tingkat Kemandirian Keuangan Daerah Kabupaten/Kota Provinsi Jawa Barat} 2014-2017

\begin{tabular}{cclc}
\hline $\begin{array}{c}\text { Tahu } \\
\mathbf{n}\end{array}$ & $\begin{array}{c}\text { Persentas } \\
\mathbf{e}\end{array}$ & $\begin{array}{c}\text { Kemandiria } \\
\text { n Keuangan } \\
\text { Daerah }\end{array}$ & $\begin{array}{c}\text { Pola } \\
\text { Hubunga } \\
\mathbf{n}\end{array}$ \\
\hline $\mathbf{2 0 1 4}$ & $26 \%$ & Rendah & Konsultatif \\
$\mathbf{2 0 1 5}$ & $28 \%$ & Rendah & Konsultatif \\
$\mathbf{2 0 1 6}$ & $29 \%$ & Rendah & Konsultatif \\
$\mathbf{2 0 1 7}$ & $36 \%$ & Rendah & Konsultatif \\
\hline \multicolumn{4}{l}{ Sumber: Direktorat Jenderal Perimbangan } \\
Keuangan Kementrian Keuangan Republik \\
Indonesia
\end{tabular}

Faktor-faktor yang dapat dilihat mempengaruhi Tingkat Kemandirian Keuangan suatu daerah masi terus dikaji oleh berbagai penelitian. Penelitian terdahulu terkait dengan faktor yang mempengaruhi Tingkat Kemandirian Keuangan suatu daerah telah banyak dilakukan, namun masih terdapat inkonsistensi hasil dari penelitian yang ditemukan. Maka dari itu penelitian ini dilakukan untuk menguji beberapa faktor yang diduga dapat berpengaruh terhadap Tingkat Kemandirian Keuangan Daerah secara simultan maupun parsial antara lain Pendapatan Asli Daerah (PAD), Dana Alokasi Umum (DAU), serta Belanja Modal pada kabupaten/kota provinsi Jawa Barat tahun 2014-2017.

\section{Pengembangan Hipotesis} Agency Theory

Menurut Halim dan Syukriy dalam (Erawati, 2015) teori keagenan adalah teori yang menjelaskan hubungan kontraktual antara prinsipal dan agen yang salah satunya berakar pada teori ekonomi, teori keputusan, sosiologi, dan teori organisasi yang dimana pihak principal berharap pihak agen akan bertindak/melakukan pekerjaan yang sesuai dengan yang diinginkan (dalam hal ini terjadi pendelegasian wewenang). Dalam 
pemerintahan pihak yang berperan sebagai pricipal atau pemberi wewenang adalah pemerintah pusat, sedangkan yang berperan sebagai agen atau yang melaksanakan tugas/wewenang adalah pemerintah daerah.

Pemerintah pusat akan mendelegasikan wewenang kepada pemerintah daerah untuk mengelola pemerintahannya sendiri tetapi tetap pemerintah pusat tidak sepenuhnya lepas tangan. Salah satu bukti campur tangan pemerintah pusat adalah dengan memberikan bantuan berupa dana perimbangan yang bertujuan untuk membantu mendanai kebutuhan daerah dengan harapan daerah bisa mandiri dalam menghasilkan pedapatan asli daerahnya sendiri pada masa yang akan datang. Tetapi pada teori ini menganggap bahwa pihak agen tidak dapat dipercaya untuk bertindak dengan sebaik-baiknya bagi kepentingan principal. Pihak agen mengelola pemerintahan daerahnya masih dengan ketergantungan pada pemberian bantuan dana perimbangan yang menyebabkan menjadi tidak mandirinya daerah tersebut. Perbedaan kepentingan antar principal dan agen ini menjadi dasar munculnya teori ini.

Pendapatan Asli Daerah terhadap Tingkat Kemandirian Keuangan Daerah

Menurut Undang-Undang Nomor 33 Tahun 2004 tentang Perimbangan Keuangan antara Pemerintah Pusat dan Pemerintah Daerah adalah pendapatan atau penerimaan daerah yang diperoleh dengan dipungut berdasarkan peraturan daerah sesuai dengan peraturan perundangundangan. Menurut Marizka (2013)Pendapatan Asli Daerah (PAD) dapat diukur dengan menggunakan rasio kontribusi PAD sebagai berikut:

$$
\text { Kontribusi PAD }=\frac{P A D}{\text { Total Pendapatan Daerah }}
$$

Menurut Susanti (2016) apabila suatu daerah memiliki tingkat PAD meningkat maka Tingkat Kemandirian Keuangan Daerah tersebut pun akan meningkat. Hasil penelitian Susanti et al (2016) menyatakan bahwa Pendapatan Asli Daerah (PAD) memiliki pengaruh positif terhadap Tingkat Kemandirian Keuangan Daerah (TKKD).

Dana Alokasi Umum (DAU) terhadap Tingkat Kemandirian Keuangan Daerah.

Dana Alokasi Umum yang selanjutnya disebut DAU didefinisikan menurut UU No.33 Tahun 2004 [12] tentang Perimbangan Keuangan sebagai dana yang bersumber dari pendapatan Anggaran Pendapatan dan Belanja Negara (APBN) yang dialokasikan untuk provinsi dan kabupaten/kota dengan tujuan pemerataan kemampuan keuangan antardaerah untuk mendanai kebutuhan daerah dalam rangka pelaksanaan desentralisasi. Menurut Marizka (2013) Dana Alokasi Umum dapat diukur dengan mencari kontribusi terhadap total pendapatan daerah. Pengukurannya yaitu dengan membandingkan Dana Alokasi Umum dengan Total Pendapatan Daerah. Untuk menghitung kontribusi dana alokasi umum dapat menggunakan rumus:

$$
\text { Kontribusi DAU }=\frac{D A U}{\text { Total Pendapatan Daerah }}
$$

Apabila tingkat Dana Alokasi Umum (DAU) yang dimiliki suatu daerah meningkat dari tahun sebelumnya, maka Tingkat Kemandirian Keuangan Daerah (TKKD) akan menurun (Marizka,2013). Hasil penelitian yang dilakukan Ariani dan Putri (2016) menyatakan bahwa Dana Alokasi Umum memiliki pengaruh negatif 
terhadap Tingkat Kemandirian Keuangan Daerah. Belanja

Modal terhadap Tingkat Kemandirian Keuangan Daerah.

Menurut UU No.18 Tahun 2016 Belanja Modal didefinisikan sebagai semua pengeluaran negara yang dilakukan dalam rangka pembentukan modal dalam bentuk tanah, peralatan dan mesin, gedung dan bangunan, jaringan, serta dalam bentuk fisik lainnya. Belanja modal dapat diukur dengan rasio belanja modal. Berdasarkan rasio ini pembaca laporan dapat mengetahui porsi belanja daerah yang dialokasikan untuk investasi dalam bentuk belanja modal pada tahun anggaran yang bersangkutan (Mahmudi, 2016:162). Rasio belanja modal ini dirumuskan sebagai berikut (Mahmudi, 2016:163):

$$
\text { Belanja Modal }=\frac{\text { Realisasi Belanja Modal }}{\text { Total Belanja Daerah }} \times 100 \%
$$

Kemandirian keuangan daerah berkaitan dengan realisasi pendapatan terhadap anggaran pendapatan daerah sehingga penyerapan belanja modal yang baik akan membantu pemerintah daerah meningkatkan kemandirian keuangan daerah (Nur'ainy et al, 2013). Tingkat Belanja Modal memiliki pengaruh positif terhadap Tingkat Kemandirian Keuangan Daerah (TKKD) (Ariani dan Putri, 2016).

Hipotesis

$\mathrm{H}_{1}$ : Pendapatan Asli Daerah, Dana Alokasi Umum, serta Belanja Modal berpengaruh secara simultan terhadap Tingkat Kemandirian Keuangan Daerah

$\mathrm{H}_{2}$ : Pendapatan Asli Daerah (PAD) berpengaruh positif terhadap Tingkat Kemandirian Keuangan Daerah.

$\mathrm{H}_{3}$ : Dana Alokasi Umum berpengaruh negatif terhadap Tingkat Kemandirian Keuangan Daerah.
$\mathrm{H}_{4}$ : Belanja Modal berpengaruh positif terhadap Tingkat Kemandirian Keuangan Daerah

\section{Metode, Data dan Analisis}

Untuk menguji hipotesis yang telah dirumuskan, penelitian ini menggunakan metode kuantitatif karena penelitian ini melibatkan perhitungan angka atau kuantifikasi data, serta data yang dikumpulkan melalui pengukuran dengan menggunakan alat yang objektif dan baku (Sujarweni, 2015:46). Teknik pengumpulan data yang digunakan adalah dokumentasi laporan keuangan dan studi kepustakaan. Populasi yang digunakan di dalam penelitian ini adalah Laporan Keuangan Pemerintah Daerah Kabupaten/Kota di Provinsi Jawa Barat tahun 2014-2017. Teknik sampling dalam penelitian ini menggunakan metode sensus sampling atau sampel jenuh. Dari pengambilan sampel tersebut diperoleh 108 sampel yang terdiri dari 27 Kabupaten/Kota selama 4 tahun. Model analisis yang digunakan adalah analisis regresi data panel dengan menggunakan software Eviews 9.0 dengan melakukan beberapa tahap pengujian.

Tabel 2 Jumlah Sampel Penelitian Jumlah Kabupaten/Kota di 27 Provinsi Jawa Barat

\begin{tabular}{ll}
\hline Tahun Pengamatan & 4 \\
Jumlah Data Pengamatan & 108 \\
2014-2017 $(27 \times \mathbf{4})$ & \\
\hline \multicolumn{2}{l}{ Sumber: Data yang diolah penulis $(2018)$} \\
\multicolumn{2}{c}{ Variabel dependen yang digunakan } \\
dalam penelitian ini adalah Tingkat \\
Kemandirian Keuangan Daerah. Variabel \\
independen yang digunakan diantaranya \\
Pendapatan Asli Daerah, Dana Alokasi \\
Umum, dan Belanja Modal.
\end{tabular}




\section{Hasil dan Diskusi}

Analisis Regresi Data Panel

Berdasarkan hasil pemilihan model regresi dengan menggunakan uji chow dan uji hausman disimpulkan bahwa model yang digunakan adalah model fixed effect. Berikut ini adalah persamaan regresi data panel dengan menggunakan fixed effect model.

$$
\begin{gathered}
\text { TKKD }=-1,186901+5,604415 X 1 \\
-0,393682 X 2 \\
-0,200230 X 3+\varepsilon
\end{gathered}
$$

Keterangan

$$
\begin{array}{ll}
\text { TKKD } & \text { : Tingkat Kemandirian Keuangan } \\
& \text { Daerah } \\
\mathrm{X} 1 & : \text { Pendapatan Asli Daerah } \\
\mathrm{X} 2 & \text { : Dana Alokasi Umum } \\
\mathrm{X} 3 & \text { : Belanja Modal } \\
\varepsilon & \text { : Error term }
\end{array}
$$

Penjelasan dari persamaan:

a. Nilai konstanta sebesar $-1,816901$ menunjukan bahwa apabila variabel independen pada regresi yaitu pendapatan asli daerah, dana alokasi umum, dan belanja modal bernilai konstan atau tidak berubah, maka tingkat kemandirian keuangan (TKKD) yang dimiliki oleh Kabupaten/Kota Provinsi Jawa Barat adalah sebesar 1,816901 .

b. Koefisien regresi pendapatan asli daerah (X1) sebesar 5,604415 maka menunjukkan bahwa apabila terjadi peningkatan pendapatan asli daerah sebesar satu satuan maka tingkat kemandirian keuangan daerah (TKKD) yang dimiliki Kabupaten/Kota Provinsi Jawa Barat akan mengalami peningkatan 5,604415.

c. Koefisien regresi dana alokasi umum (X2) sebesar -0,393682 maka menunjukkan bahwa apabila terjadi penurunan dana alokasi umum sebesar satu satuan maka tingkat kemandirian keuangan daerah (TKKD) yang dimiliki Kabupaten/Kota Provinsi Jawa Barat akan mengalami penurunan sebesar 0,393682.

d. Koefisien regresi belanja modal (X3) sebesar -0,200230 maka menunjukkan bahwa apabila terjadi penurunan belanja modal sebesar satu satuan maka tingkat kemandirian keuangan daerah (TKKD) yang dimiliki Kabupaten/Kota Provinsi Jawa Barat akan mengalami penurunan sebesar 0,200230 .

Pembahasan Hasil Penelitian

1. Pengaruh Pendapatan Asli Daerah, Dana Alokasi Umum, dan Belanja Modal terhadap Tingkat Kemandirian Keuangan Daerah.

Berdasarkan Tabel 4.15 diperoleh bahwa nilai probabilitas (F-statistic) sebesar $0.000000<0.05$, maka artinya pendapatan asli daerah, dana alokasi umum, dan belanja modal secara simultan berpengaruh terhadap tingkat kemandirian keuangan daerah Kabupaten/Kota di Provinsi Jawa Barat tahun 2014-2017.

2. Pengaruh Pendapatan Asli Daerah terhadap Tingkat Kemandirian Keuangan Daerah.

Berdasarkan hasil pengujian secara parsial, nilai probabilitas variabel independen pendapatan asli daerah sebesar 0,0000. Nilai tersebut menunjukan angka lebih kecil dari 0,05. Hal tesebut menunjukan bahwa pendapatan asli daerah berpengaruh terhadap tingkat kemandirian keuangan daerah. Dilihat dari nilai koefisien 5,604415 dapat disimpulkan bahwa variabel PAD mempunyai pengaruh yang positif terhadap TKKD. Hasil tersebut sesuai dengan kerangka pemikiran yang menyatakan bahwa dengan semakin tinggi PAD, maka TKKD akan semakin meningkat begitu pun sebaliknya. 
3. Pengaruh Dana Alokasi Umum terhadap Tingkat Kemandirian Keuangan Daerah.

Berdasarkan pada pengujian hipotesis secara parsial yang telah dilakukan, DAU memiliki nilai probabilitas $0,1376>0,05$, maka sesuai dengan ketentuan maka H01 diterima dan Ha1. Hal tersebut dapat diartikan bahwa DAU tidak berpengaruh signifikan terhadap TKKD. Apabila tingkat DAU yang diperoleh oleh suatu daerah meningkat atau tinggi, maka TKKD suatu daerah tersebut belum tentu akan meningkat pula. Begitupun apabila tingkat DAU yang diperoleh suatu daerah menurun atau rendah, maka TKKD suatu daerah tersebut belum tentu akan menurun pula.

Hasil pengujian secara parsial menyatakan bahwa DAU tidak memiliki pengaruh signifikan terhadap TKKD suatu daerah dikarenakan DAU hanya satu dari tiga komponen Dana Perimbangan yang termasuk dalam perhitungan TKKD suatu daerah. Dana Alokasi Umum merupakan dana yang bersumber dari pendapatan Anggaran Pendapatan dan Belanja Negara (APBN) yang dialokasikan untuk provinsi dan kabupaten/kota dengan tujuan pemerataan kemampuan keuangan antardaerah untuk mendanai kebutuhan daerah dalam rangka pelaksanaan desentralisasi. Penggunaan DAU sepenuhnya diserahkan kepada kebijakan pemerintahan daerah masing-masing untuk digunakan membantu membiayai pembangunan di daerah. DAU termasuk kedalam komponen Dana Perimbangan yang dimana Dana Perimbangan termasuk dalam perhitungan penentuan TKKD suatu daerah. TKKD suatu daerah ditentukan dengan membagi PAD yang dimiliki daerah tersebut dengan transfer pusat dan provinsi serta pinjaman, yang dimana transfer pusat dan provinsi serta pinjaman dapat berupa DAU, DAK, dan dana bagi hasil yang terdapat dalam komponen Dana Perimbangan, serta dana hibah dan dana darurat yang terdapat dalam komponen lain-lain pendapatan daerah yang sah. Sehingga DAU tidak berpengaruh signifikan terhadap TKKD suatu daerah.

Hasil penelitian ini sejalan dengan penelitian yang telah dilakukan Marizka (2013) yang menyatakan bahwa Dana Alokasi Umum tidak berpengaruh signifikan terhadap Tingkat Kemandirian Keuangan Daerah.

4. Pengaruh Belanja Modal terhadap Tingkat Kemandirian Keuangan Daerah.

Berdasarkan pengujian hipotesis secara parsial yang telah dilakukan, Belanja Modal (BM) memiliki nilai probabilitas $0,0160<0,05$. Dapat dilihat juga nilai koefisien variabel Belanja Modal sebesar -0,200230. Hal tersebut dapat diartikan bahwa variabel Belanja Modal berpengaruh negatif terhadap TKKD.

Belanja modal merupakan semua pengeluaran negara yang dilakukan dalam rangka pembentukan modal dalam bentuk tanah, peralatan dan mesin, gedung dan bangunan, jaringan, serta dalam bentuk fisik lainnya yang mempunyai nilai manfaat lebih dari 12 (dua belas) bulan untuk digunakan dalam kegiatan pemerintahan. Menurut Ariani dan Putri (2016) yang menyatakan bahwa sebuah pemerintahan dengan kualitas pelayanan publik yang baik selalu diikuti dengan tingginya partisipasi publik terhadap pembangunan yang dicerminkan dengan tingginya Pendapatan Asli Daerah (PAD) yang digunakan pemerintah daerah tersebut untuk belanja daerah termasuk belanja modal yang kemudian diwujudkan ke dalam pembangunan daerah dan perbaikan infrastruktur daerah di berbagai sektor.

Hasil pengujian secara parsial yang telah dilakukan menyatakan bahwa 
variabel belanja modal berpengaruh negatif terhadap TKKD dikarenakan belanja modal yang dikeluarkan sebuah pemerintah daerah tidak selalu akan berdampak pada kenaikan TKKD. Pengeluaran yang digunakan untuk perbaikan jalan atau pembangunan irigasi di desa-desa yang berada di kabupaten/kota hanya sebagai bentuk pelayanan fasilitas kepada publik, hal tersebut tidak akan menambah pendapatan asli daerah yang dihasilkan daerah tersebut melainkan hal tersebut akan meningkatkan jumlah pengeluaran yang harus didanai oleh daerah menggunakan pendapatan asli daerah bahkan menggunakan dana alokasi umum yang diberikan pemerintah pusat. Contoh lainnya pembelian tanah atau bangunan sebagai aset daerah tanpa dikelola dengan baik sehingga hanya menjadi aset terbengkalai juga misalnya, tidak akan menambah pendapatan asli daerah yang akan menjadikan daerah tersebut mandiri.

Hasil penelitian ini sejalan dengan penelitian yang telah dilakukan oleh Darwis (2015) yang menyatakan bahwa belanja modal berpengaruh signifikan negatif terhadap tingkat kemandirian keuangan daerah.

\section{Kesimpulan, Keterbatasan dan Saran} Kesimpulan

Berdasarkan hasil analisis deskriptif dan pengujian regresi data panel dapat diperoleh kesimpulan bahwa secara simultan pendapatan asli daerah, dana alokasi umum, dan belanja modal berpengaruh terhadap tingkat kemandirian keuangan. Secara parsial pendapatan asli daerah berpengaruh positif tehadap tingkat kemandirian keuangan daerah, dana alokasi umum tidak berpengaruh terhadap tingkat kemandirian keuangan daerah, belanja modal berpengaruh negatif terhadap tingkat kemandirian keuangan daerah.

\section{Keterbatasan}

Penelitian atau data observasi yang digunakan hanya pada kabupaten/kota provinsi Jawa Barat, sehingga tingkat generalisasi hasil penelitian masih terbatas sehingga hasil tidak dapat menggeneralisasi kondisi pada kabupaten/kota provinsi lain di Indonesia.

Saran

1. Peneliti

Untuk penelitian selanjutnya, peneliti menyarankan untuk mencari sumber data baru selain website resmi Direktorat Jenderal Perimbangan Keuangan (www.djpk.kemenkeu.go.id) dalam mengambil data laporan keuangan yang digunakan untuk penelitian. Hal tersebut dikarenakan ketersediaan data di website tersebut cukup terbatas. Selain itu, peneliti juga menyarankan bagi peneliti selanjutnya untuk menambahkan periode penelitian serta memilih objek lainnya.

2. Pemerintah

Bagi pemerintah, hasil penelitian ini diharapkan dapat memberikan gambaran kepada pemerintah dalam mencari solusi meningkatkan pendapatan asli daerah sehingga dapat meningkatkan tingkat kemandirian keuangan daerah. Dengan demikian dana alokasi umum yang dialokasikan pemerintah pusat kepada pemerintah daerah dapat berkurang dan pemerintah daerah dapat membiayai kebutuhan operasional maupun belanja daerahnya dengan menggunakan pendapatan asli daerah yag dihasilkan daerahnya sendiri.

3. Masyarakat

Bagi masyarakat, hasil penelitian ini diharapkan dapat memberikan informasi atau gambaran kepada masyarakat mengenai tingkat kemandirian keuangan 
daerahnya agar masyarakat dapat ikut berkontribusi dalam mengevaluasi untuk meningkatkan tingkat kemandirian keuangan daerah yang ada di Indonesia.

\section{DAFTAR PUSTAKA}

Ariani, K., \& Putri, G. (2015). Pengaruh Belanja Modal dan Dana Alokasi Umum terhadap Tingkat Kemandirian Keuangan Daerah. Seminar Nasional dan The 3rd Call for Syariah Paper; ISSN: 24600784.

Erawati, N. T., \& Suzan, L. (2015). Pengaruh Pendapatan Asli Daerah terhadap Tingkat Kemandirian Keuangan Daerah Kota Bandung Periode 2009-2013. E-Proceeding of Management: Vol.2, No.3, ISSN:2355-9357, 3259.

Mahmudi. (2016). Analisis Laporan Keuangan Pemerintah Daerah. Yogyakarta: Unit Penerbit dan Percetakan Sekolah Tinggi Ilmu Manajemen YKPN.

Marizka, R. (2013). Pengaruh Pendapatan Asli Daerah, Dana Bagi Hasil, Dana Alokasi Umum dan Dana Alokasi Khusus Terhadap Tingkat Kemandirian Keuangan Daerah pada Kabupaten dan Kota di Sumatera Barat (Tahun 20062011). Jurnal Perspektif dan Pembangunan Daerah Vol.1 No.2; ISSN:1979-7338.

Nur'ainy, R., Desfitrina, \& Utomo, R. (2013). Pengaruh Pertumbuhan Ekonomi dan Pendapatan Asli Daeah terhadap Tingkat Kemandirian Keuangan Daerah (Studi Kasus Pada Kota Di Jawa Barat). Proceeding Psikologi, Ekonomi, Sastra, Arsitektur \& Teknik Sipil) Vol.5; ISSN: 18582559.
Sujarweni, V. (2015). Metodologi Penelitian Bisnis dan Ekonomi. Yogyakarta:

PUSTAKABARUPRESS.

Susanti, D. B., Rahayu, S., \& Yudowati, S. (2016, December). Pengaruh Pendapatan Asli Daerah, Dana Alokasi Umum, dan Dana Alokasi Khusus terhadap Tingkat Kemandirian Keuangan Daerah (Studi pada Kota/Kabupaten di Provinsi Jawa Barat Tahun 20102014). E-Proceeding of Management : Vol.3, No.3, ISSN: 2355-9357, 3308.

Yulihantini, D., Sukarno, H., \& Wardayati, S. (2018). Pengaruh Belanja Modal dan Alokasi Dana Desa terhadap Kemandirian dan Kinerja Keuangan Desa Di Kabupaten Jember. Jurnal Bisnis dan Manajemen Vol.12 No.1, , 37-50.

Undang Undang No.33 Tahun 2004 tentang Perimbangan Keuangan.

Undang Undang No.24 Tahun 2014 tentang Pemerintahan Daerah.

Undang Undang No.8 Tahun 2017 tentang tentang Anggaran Pendapatan dan Belanja Negara. 